\title{
Partial Replacement of Biomedical Waste ASH in Concrete
}

\author{
Sathvik S, Suchith. S, Edwin. A, Jemimahcarmicheal. M, Sheela. V
}

\begin{abstract}
Cement is a binder, a substance used for construction that sets, hardens and adhering to other materials, binding them together. Cement is seldom used on its own, but rather to bind sand and gravel together. Cement is used with fine aggregates to produce mortar for masonry, or with sand and gravel aggregates to produce concrete. Concrete is a composite material composed of fine and coarse aggregate bonded together with a fluid cement that hardens over time. Annual production of cement is nearly 425 million tonnes, India is the second largest cement producer in the world and accounts for 6.9 percent of worlds cement output. Biomedical waste, generated from medical sources and activities is a cause of concern for environmentalist. These wastes are generated in the process of diagnosis treatment and similar activities pertaining to human and animals. Also in the production or testing of biological instruments/components. Biological waste is broadly classified as biological and nonbiological wastes that may or may not be infectious.
\end{abstract}

\section{INTRODUCTION}

According to ministry of environment and forest about $4,05,702 \mathrm{~kg}$ biomedical waste generated every day in India out of which around $72 \%$ is disposed off. However more than $28 \%$ is biomedical waste is left unattended. Most common process of disposal of biomedical waste is incineration in specifically made for biomedical waste. Ash obtained after incineration of biomedical waste are used as landfill. However, these wastes can effectively been used in concrete making which will result in reduce the demand of land for disposal of biomedical waste ash on one hand and protection of environment by reducing the consumption and production of cement on other hand.

Toxicity and potential hazards of biomedical waste is generally depend upon its origin. It contains heavy toxic metals which are very harmful for human body. At present 170 common biomedical waste treatment facilities are available having 140 incinerators throughout the country. Biomedical waste can be used in concrete with replacement by weight for cement. The addition of hospital waste ash in cement matrices can be used as construction material. It can also be used as a stabilizing agent in road and asphalt pavements.

Revised Manuscript Received on April 12, 2019.

Sathvik S, Dept. of Civil Engineering, SRM Institute of Science and Technology, Kattankulathur, T.N., India.

Suchith. S, Dept. of Civil Engineering, SRM Institute of Science and Technology, Kattankulathur, T.N., India

Edwin. A, Dept. of Civil Engineering, SRM Institute of Science and Technology, Kattankulathur, T.N., India(E-mail: edwinraj91@gmail.com)

Jemimahcarmicheal. M, Dept. of Civil Engineering, Karunya Institute of and Technology and Sciences, Coimbatore, Tamil Nadu, India.

Sheela. V, Dept. of Civil Engineering, Karunya Institute of and Technology and Sciences, Coimbatore, Tamil Nadu, India.

\section{MATERIALS IN CONCRETE}

In the present investigation and experimental program was carried out to investigate the suitability of use of biomedical waste ash as partial replacement of cement in concrete and effect of replacement of cement of biomedical waste ash on workability of concrete in general and on compressive strength in particular.

\section{A. CEMENT (Portland cement 53 grade)}

In the present study, Portland Pozzolanacement (fly ash based) of single lot. The cement is used confirming to IS 1489(part I): 1991 specification.

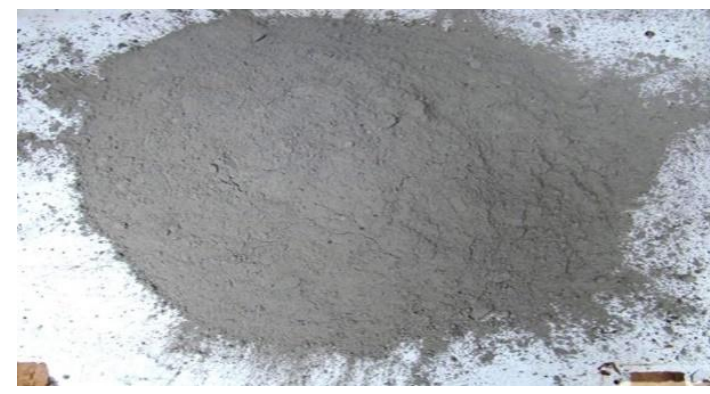

Fig.1 Cement

Cement is a binder, a substance used in construction that sets, hardens and adheres to other materials, binding them together. Cement is seldom used solely, but is used to bind sand and gravel (aggregate) together. Cement is used with fine aggregate to produce mortar for masonry, or with sand and gravel aggregates to produce concrete.Non-hydraulic cement will not set in wet conditions or underwater; rather, it sets as it dries and reacts with carbon dioxide in the air. It is resistant to attack by chemicals after setting.Hydraulic cements (e.g., Portland cement) set and become adhesive due to a chemical reaction between the dry ingredients and water. The chemical reaction results in mineral hydrates that are not very water-soluble and so are quite durable in water and safe from chemical attack. This allows setting in wet condition or underwater and further protects the hardened material from chemical attack. The chemical process for hydraulic cement found by ancient Romans used volcanic ash (pozzolana) with added lime (calcium oxide).

\section{B. FINE AGGREGATES (Natural Sand)}

Fine aggregate used in this experiment is the natural river sand passing completely through $4.75 \mathrm{~mm}$ aperture size sieve and confirming to the gradation zone I as per IS:383-

Published By: 
1970 specification. Fine aggregates generally consist of natural sand or crushed stone with most particles passing through a $9.5 \mathrm{~mm}$ sieve. Fine aggregates generally consist of natural sand or crushed stone with most particles passing through a $3 / 8$-inch sieve. Fine aggregate is natural sand which has been washed and sieved to remove particles larger than $5 \mathrm{~mm}$. The code to be referred to understand the specification for fine aggregates is: IS 383:1970.

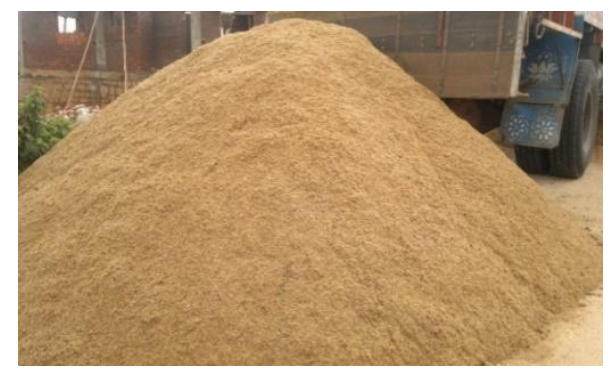

Fig.2 Fine aggregates

\section{COARSE AGGREGATE}

Coarse aggregates are particles greater than $4.75 \mathrm{~mm}$, but generally range between $9.5 \mathrm{~mm}$ to $37.5 \mathrm{~mm}$ in diameter. They can either be from Primary, Secondary or Recycled sources. Coarse aggregates are components found in many areas of the construction industry. They have structural uses such as a base layer or drainage layer below pavements and in mixtures like asphalt and concrete. This lesson explores the various types of coarse aggregates. Coarse aggregate is mined from rock quarries or dredged from river beds, therefore the size, shape, hardness, texture and many other properties can vary greatly based on location. Even materials coming from the same quarry or pit and type of stone can vary greatly. Most generally, coarse aggregate can be characterized as either smooth or rounded (such as river gravel) or angular (such as crushed stone). Because of this variability, test methods exist to characterize the most relevant characteristics since exact identification would be impossible. Several key characteristics that are frequently used to describe the behavior of coarse aggregates include relative density (or specific gravity), bulk density, and absorption.

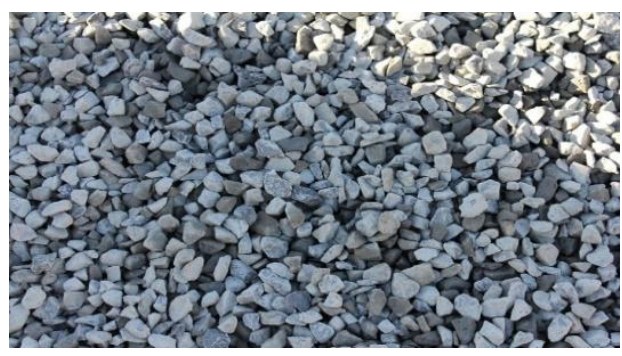

Fig.3 Coarse aggregates

\section{WATER}

Water is a transparent and nearly colourless chemical substance that is the main constituent of Earth's streams, lakes, and oceans, and the fluids of most living organisms. Theamount of water in concrete controls many fresh and hardened properties in concrete including workability, compressive strengths, permeability and water tightness, durability and weathering, drying shrinkage and potential for cracking. For these reasons, limiting and controlling the amount of water in concrete is important for both constructability and service life.Portable water is used for the preparation of cement composites mixing and curing. The $\mathrm{pH}$ value of water is 6.5 and all the other contents of water are as per Indian Standards.

\section{BIOMEDICAL WASTE ASH}

Biomedical waste ash which is used throughout this experiment was collected from Maridi Eco Industry Private Limited, Bangalore.The type of waste ash collected are primary ash and secondary ash.

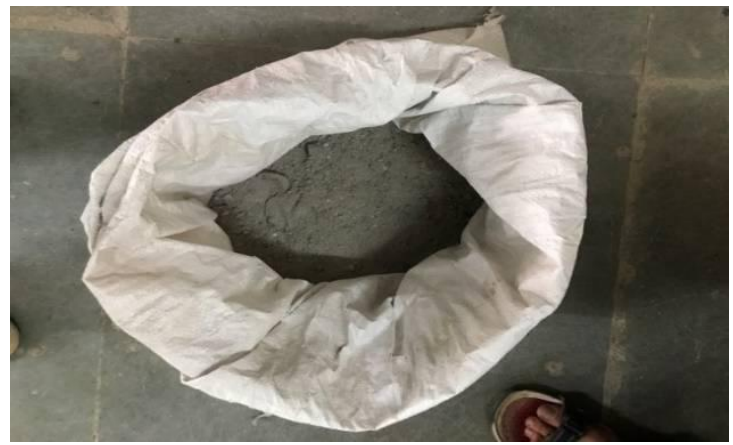

Fig. 4 Bio medical waste ash

The water cement ratio was taken as 0.5 which should be the maximum for M20 grade under mild exposure condition.

V. MIX DESIGN OF M25DESIGN STIPULATION

\begin{tabular}{|c|c|c|}
\hline [1] Sl.no. & $\begin{array}{ll}\text { [2] } & \text { DESIGN } \\
& \text { STIPULATIONS } \\
\end{array}$ & [3] QUANTITY \\
\hline [4] 1. & 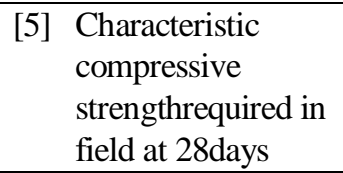 & [6] $20 \mathrm{~N} / \mathrm{mm}^{2}$ \\
\hline [7] 2 . & $\begin{array}{l}\text { [8] Maximum size of } \\
\text { aggregate }\end{array}$ & [9] $20 \mathrm{~mm}$ \\
\hline$[10] 3$. & $\begin{array}{l}\text { [11] Degree of quality } \\
\text { control }\end{array}$ & [12] Good \\
\hline$[13] 4$. & [14] Type of exposure & $\begin{array}{l}15] \text { Severe (for } \\
\text { plain concrete) }\end{array}$ \\
\hline
\end{tabular}

VI. TEST DATA FOR MATERIAL

\begin{tabular}{|l|l|l|}
\hline$[16]$ Sl.no. & $\begin{array}{c}\text { [17] TEST DATA FOR } \\
\text { MATERIAL }\end{array}$ & $\begin{array}{c}\text { [18] QUALIT } \\
\text { Y }\end{array}$ \\
\hline$[19] 1$. & {$[20]$ Cement used } & $\begin{array}{c}{[21] \text { OPC 53 }} \\
\text { grade }\end{array}$ \\
\hline$[22] 2$. & $\begin{array}{c}\text { [23] Specific gravity } \\
\text { ofcement }\end{array}$ & {$[24] 2.875$} \\
\hline$[25] 3$. & $\begin{array}{c}\text { [26] Specific gravity of } \\
\text { fine aggregate }\end{array}$ & {$[27] 2.82$} \\
\hline$[28] 4$. & $\begin{array}{c}\text { [29] Specific gravity of } \\
\text { coarseaggregate }\end{array}$ & {$[30] 2.78$} \\
\hline$[31] 5$. & $\begin{array}{c}\text { [32] Water absorption of } \\
\text { coarse aggregate }\end{array}$ & {$[33] 1.35 \%$} \\
\hline
\end{tabular}




\section{TEST RESULTS ANDDISCUSSIONSWORKABILITY OF CONCRETE}

Workability is often referred to as the ease with which a concrete can be transported, placed and consolidated without excessive bleeding or segregation.

\section{Workability of concrete}

\begin{tabular}{|c|l|l|}
\hline $\begin{array}{c}{[34] \mathrm{Sl}} \\
\text { no }\end{array}$ & {$[35]$} & $\begin{array}{c}{[36] \text { Slump in }} \\
\mathrm{mm}\end{array}$ \\
\hline$[37] 1$ & {$[38]$ Conventional } & {$[39] 55$} \\
\hline$[40] 2$ & {$[41] 5 \%$ Bio medical waste ash } & {$[42] 30$} \\
\hline$[43] 3$ & $\begin{array}{c}{[44] 10 \% \text { Bio medical waste }} \\
\text { ash }\end{array}$ & {$[45] 40$} \\
\hline$[46] 4$ & $\begin{array}{c}{[47] 15 \% \text { Bio medical waste }} \\
\text { ash }\end{array}$ & {$[48] 52$} \\
\hline
\end{tabular}

Workability of concrete increases with the increase in replacement of cement by biomedical waste ash and reaches a value which is almost equal to the conventional concrete.

\section{A. DENSITY OF CONCRETE}

A normal weight concrete weights $2400 \mathrm{~kg} / \mathrm{m} 3$. The unit weight of concrete (density) varies depending on the amount and density of the aggregates, the amount of entrained air (and entrapped air) and the water \& cement content.

Density of concrete for compressive strength

\begin{tabular}{|c|c|c|c|}
\hline \multirow{2}{*}{ Mix Type } & \multicolumn{3}{|c|}{ Density in kg/m } \\
\cline { 2 - 4 } & 7 days & 14 days & 28 days \\
\hline Conventional & 2425.67 & 2479.99 & 2452.34 \\
\hline $\begin{array}{c}5 \% \text { Bio medical } \\
\text { waste ash }\end{array}$ & 2415.8 & 2455.3 & 2370.37 \\
\hline $\begin{array}{c}10 \% \\
\text { medical waste ash }\end{array}$ & 2398.02 & 2374.32 & 2390.12 \\
\hline $\begin{array}{c}15 \% \text { Bio } \\
\text { medical waste ash }\end{array}$ & 2407.9 & 2427.65 & 2413.83 \\
\hline
\end{tabular}

\begin{tabular}{|c|c|c|c|c|c|c|}
\hline \multicolumn{7}{|c|}{ COMPRESSIVE STRENGTH, N/mm² } \\
\hline $\begin{array}{l}\text { Type of } \\
\text { moulds }\end{array}$ & \multicolumn{2}{|c|}{$\begin{array}{c}7 \text { days } \\
\text { strength }(\mathrm{N} / \mathrm{m} \\
\left.\mathrm{m}^{2}\right)\end{array}$} & \multicolumn{2}{|c|}{$\begin{array}{c}14 \text { days } \\
\text { strength }(\mathrm{N} / \mathrm{m} \\
\left.\mathrm{m}^{2}\right)\end{array}$} & \multicolumn{2}{|c|}{$\begin{array}{c}28 \text { days } \\
\text { strength }(\mathrm{N} / \mathrm{m} \\
\left.\mathrm{m}^{2}\right)\end{array}$} \\
\hline \multirow{3}{*}{$\begin{array}{l}\text { Conventio } \\
\text { nal }\end{array}$} & 25.38 & \multirow{3}{*}{25.03} & 27.84 & \multirow{3}{*}{28.14} & 35.64 & \multirow{3}{*}{33.33} \\
\hline & 24.8 & & 28.4 & & 32.44 & \\
\hline & 24.94 & & 27.96 & & 31.91 & \\
\hline \multirow{3}{*}{$\begin{array}{c}5 \% \text { Bio } \\
\text { medical } \\
\text { waste ash }\end{array}$} & 16.35 & \multirow{3}{*}{18.72} & 21.55 & \multirow{3}{*}{20.67} & 36.22 & \multirow{3}{*}{34.82} \\
\hline & 18.04 & & 18 & & 32.48 & \\
\hline & 21.78 & & 20 & & 35.77 & \\
\hline \multirow{3}{*}{$\begin{array}{l}10 \% \text { Bio } \\
\text { medical } \\
\text { waste ash }\end{array}$} & 15.87 & \multirow{3}{*}{20.32} & 21.55 & \multirow{3}{*}{22.25} & 31.2 & \multirow{3}{*}{28.55} \\
\hline & 24.08 & & 20.04 & & 22.44 & \\
\hline & 21.02 & & 20.44 & & 32 & \\
\hline \multirow{3}{*}{$\begin{array}{l}15 \% \text { Bio } \\
\text { medical } \\
\text { waste ash }\end{array}$} & 15.64 & \multirow{3}{*}{16.91} & 21.64 & \multirow{3}{*}{19.85} & 17.86 & \multirow{3}{*}{20.07} \\
\hline & 18.22 & & 22 & & 20.08 & \\
\hline & 16.88 & & 23.11 & & 22.26 & \\
\hline
\end{tabular}

Density of concrete for split tensile strength

\begin{tabular}{|c|c|c|c|}
\hline \multirow[b]{2}{*}{ Mix Type } & \multicolumn{3}{|c|}{ Density in $\mathrm{kg} / \mathrm{m}^{3}$} \\
\hline & 7 days & 14 days & 28 days \\
\hline Conventional & 2307.1 & 2293.9 & 2408.9 \\
\hline
\end{tabular}

\begin{tabular}{|c|c|c|c|}
\hline & & & 8 \\
\hline $\begin{array}{l}5 \% \text { Bio medical } \\
\text { waste ash }\end{array}$ & 2356.15 & $\begin{array}{r}2333.5 \\
1\end{array}$ & $\begin{array}{l}2371.2 \\
5\end{array}$ \\
\hline $\begin{array}{l}10 \% \text { Bio medical } \\
\text { waste ash }\end{array}$ & 2310.88 & $8^{2339.1}$ & $7^{2297.6}$ \\
\hline $\begin{array}{l}15 \% \text { Bio medical } \\
\text { waste ash }\end{array}$ & 2327.85 & $2^{2305.2}$ & $7^{2312.7}$ \\
\hline
\end{tabular}

The density of biomedical waste ash concrete is almost equal to that of conventional concrete which is $2400 \mathrm{~kg} / \mathrm{m}^{3}$.

\section{B. COMPRESSIVE STRENGTH}

Compression test is the most common test conducted on hardened cement composites partly because it is an easy test to perform and partly because most of the desirable characteristic properties of concrete or qualitative related to its compressive strength. The compressive test is carried out on specimens of cubical or cylindrical. The cube specimen is of size $100 \times 100 \times 100 \mathrm{~mm}$. The compressive strength of concrete on standard $100 \mathrm{~mm}$ cube is calculated using the formula $\mathrm{f}=\mathrm{P} / \mathrm{AN} / \mathrm{mm}^{2}$

where, $\mathrm{f}=$ compressive strength of cement composite in $\mathrm{N} / \mathrm{mm}^{2}$

$\mathrm{p}=$ ultimate load resisted by cement composites in Newton's

$\mathrm{A}=$ Cross sectional area of cube specimen in $\mathrm{mm}^{2}$

Table Readings of Compressive strength

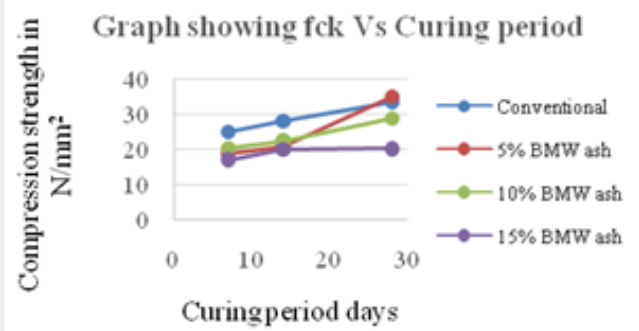

Fig.5 Plot of compressive strength v/s curing period

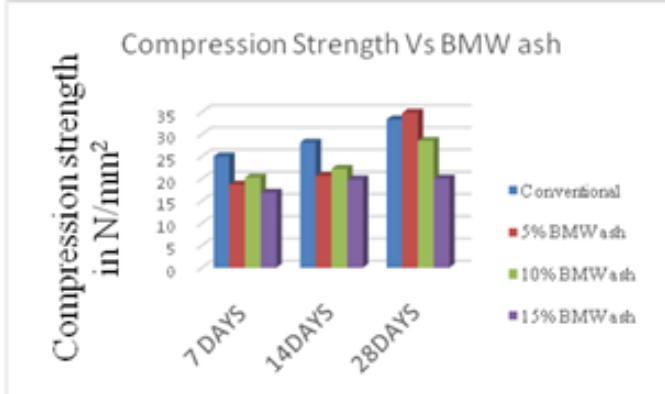

Fig.6 Plot of compressive strength v/s BMW ash

The compressive strength of concrete decreased with addition of BMW ash when compared to conventional concrete. Compressive strength of the BMW ash for 5\% and $10 \%$ replacement has shown a good results while $15 \%$ replacement strength reduced when compared to $5 \%$ and $10 \%$ strength. This effect is may be due to reduction in density of the BMW ash concrete. 


\section{SPLIT TENSILE STRENGTH}

Test is carried out by placing a cylindrical specimen horizontally between the loading surfaces of the compression test machine until failure of the specimen along the vertical diameter. The split tensile test is carried out on cylindrical specimen. The specimen is of size $100 \mathrm{~mm}$ diameters with $150 \mathrm{~mm}$ length. The split tensile strength of concrete is given by the formula $\mathrm{Ft}=2 \mathrm{P} / \Pi \mathrm{d} \mathrm{LN} / \mathrm{mm}^{2}$

Where, $\mathrm{P}=$ failure load of specimen in Newton's

$\mathrm{d}=$ diameter of specimen in $\mathrm{mm}$

$\mathrm{L}=$ length of the specimen in $\mathrm{mm}$

\section{Readings of split tensile strength}

\begin{tabular}{|c|c|c|c|c|c|c|}
\hline \multicolumn{7}{|c|}{ SPLIT TENSILE STRENGTH, N/mm ${ }^{2}$} \\
\hline $\begin{array}{l}\text { Type of } \\
\text { moulds }\end{array}$ & \multicolumn{2}{|c|}{$\begin{array}{l}7 \text { days } \\
\text { strength }(\mathrm{N} / \mathrm{m} \\
\mathrm{m} 2)\end{array}$} & \multicolumn{2}{|c|}{$\begin{array}{l}14 \text { days } \\
\text { strength }(\mathrm{N} / \mathrm{m} \\
\mathrm{m} 2)\end{array}$} & \multicolumn{2}{|c|}{$\begin{array}{l}28 \text { days } \\
\text { strength }(\mathrm{N} / \mathrm{m} \\
\mathrm{m} 2)\end{array}$} \\
\hline \multirow{2}{*}{$\begin{array}{c}\text { Conventio } \\
\text { nal }\end{array}$} & 2.35 & \multirow{2}{*}{2.31} & 2.66 & \multirow{2}{*}{2.68} & 3.37 & \multirow{2}{*}{3.39} \\
\hline & 2.27 & & 2.70 & & 3.41 & \\
\hline \multirow{2}{*}{$\begin{array}{c}5 \% \text { Bio } \\
\text { medical } \\
\text { waste ash }\end{array}$} & 1.78 & \multirow[b]{2}{*}{2.28} & 2.7 & \multirow[b]{2}{*}{2.71} & 2.6 & \multirow[b]{2}{*}{2.42} \\
\hline & 2.78 & & 2.73 & & 2.25 & \\
\hline \multirow{2}{*}{$\begin{array}{c}10 \% \text { Bio } \\
\text { medical } \\
\text { waste ash }\end{array}$} & 2.64 & \multirow[b]{2}{*}{2.33} & 3.09 & \multirow[b]{2}{*}{2.72} & 2.19 & \multirow[b]{2}{*}{2.66} \\
\hline & 2.02 & & 2.36 & & 3.13 & \\
\hline \multirow{2}{*}{$\begin{array}{c}15 \% \text { Bio } \\
\text { medical } \\
\text { waste ash }\end{array}$} & 2.12 & \multirow[b]{2}{*}{2.16} & 1.41 & \multirow[b]{2}{*}{1.44} & 1.88 & \multirow[b]{2}{*}{1.89} \\
\hline & 2.20 & & 1.47 & & 1.90 & \\
\hline
\end{tabular}

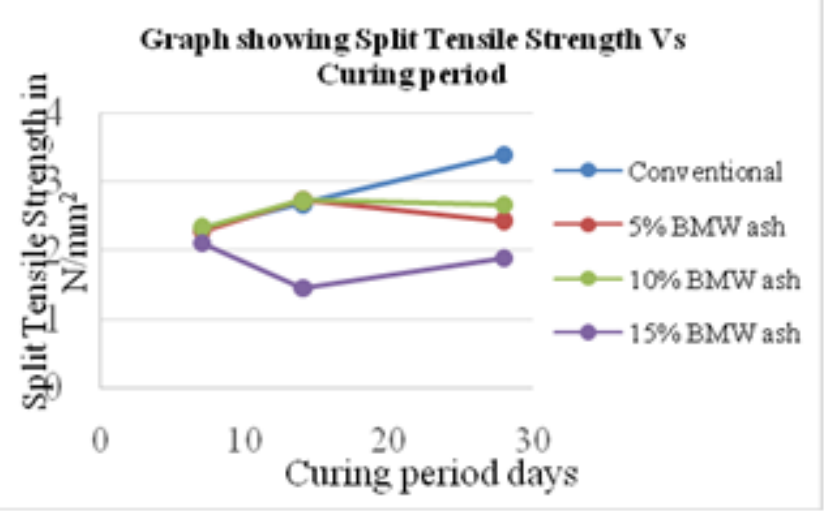

Fig.7 Plot of Split tensile strength v/s curing period

\section{Split tensile strength v/s BMW ash}

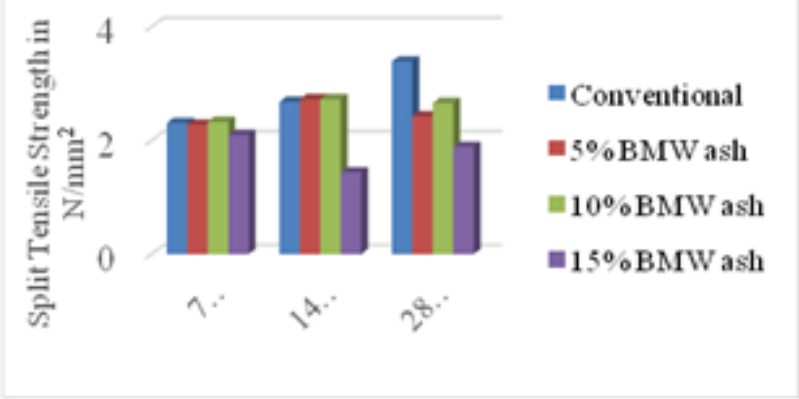

Fig 8 Plot of Split tensile strength v/s BMW ash
The Split Tensile strength of the BMW ash concrete has been reached almost the same strength of conventional concrete.Split Tensile strength of the BMW ash for 5\% and $10 \%$ replacement has shown a excellent results while $15 \%$ replacement strength reduced when compared to $5 \%$ and $10 \%$ strength

\section{CONCLUSIONS}

- It is observed that density of concrete decreased marginally with the increase in the replacement level of BMW.Biomedical waste ash can effectively be used in concrete making upto $10 \%$ replacement.

- Workability of concrete made using biomedical waste ash is lower than that of conventional concreteThe compressive strength of concrete decreased with addition of BMW ash when compared to conventional concrete.

- Compressive strength of the BMW ash for 5\% and $10 \%$ replacement has shown a good results while $15 \%$ replacement strength reduced when compared to $5 \%$ and $10 \%$ strength.

- The Split Tensile strength of the BMW ash concrete has been reached almost the same strength of conventional concrete.Split Tensile strength of the BMW ash for $5 \%$ and $10 \%$ replacement has shown a excellent results while $15 \%$ replacement strength reduced when compared to $5 \%$ and $10 \%$ strength.

- After comparing all the experimental test results, $10 \%$ replacement level is taken as the optimized percentage.

\section{REFERENCES}

1. NayefAl-Mutairi,MohammadTerro and Abdul-LateefAlKhalee, "Effect of recyclinghospital ash on the compressive properties of concrete : statistical assessment andpredicting model", December 2003.

2. AnithaRajor and Kunal, "Biomedical Waste Incinerator Ash: "A Review with Special Focus On Its Characterization, Utilization and Leachate Analysis", ISSN: 2277-2081,Volume 1, Issue 1, December 2011.

3. Shazim Ali Memon, Muhammad Ali Sheikh and Muhammad Bilal Paracha, "UtilisationOf Hospital Waste Ash In Concrete", ISSN: 0254-7821, Volume 32, Issue 1, January2013.

4. Augustine U Elinwa, "Hospital Ash Waste-Ordinary Portland Cement Concrete", Volume 4, Issue 3, June 2016

5. Udit Kumar, VikasSrivastav and Amith Kumar Singh, "Biomedical Waste Ash InConcrete: An Experimental Investigation”, ISSN: 2319-8753, Volume 5, Issue 6,June 2016.

6. Jugal V. Tailor and Parth M. Shastri, "Review on concrete from biomedical waste", ISSN: 2348-4470, February-2017.

7. K.Malavan and R.Manju, "An Experimental Investigation on Biomedical WasteConcrete”, ISSN: 2348-8352, April 2017. 